\title{
Partisipasi Masyarakat Terhadap Kegiatan Pengelolaan Daerah Aliran Sungai Cikapundung di kelurahan Dago Bandung
}

\section{Community Participation of Cikapundung Watershead Management Activities in Dago Village Bandung}

\author{
Lorenza R. Radjabaycolle ${ }^{1}$, Sumardjo ${ }^{1}$ \\ ${ }^{1}$ Departemen Sains Komunikasi dan Pengembangan Masyarakat, \\ Fakultas Ekologi Manusia, Institut Pertanian Bogor, Bogor
}

\begin{abstract}
Community participation in Cikapundung watershed management activities in Dago Village is the effort of community in maintaining and preserving the watershed. This study aims to determine the level of community participation in Dago Village on Cikapundung watershed management activities, and the factors related to the attitude of watershed management, watershed management and attitude relationship with the level of community participation. Data were analyzed using Rank spearman correlation test and the Chi-square function. This research suggests that the level of community participation in Dago Village appertain passably, and the tendency of people's attitudes in Dago Village is a major component to encourage the participate in watershed management activities.
\end{abstract}

Keywords: participation, people's behaviors

Abstrak

Partisipasi masyarakat dalam kegiatan pengelolaan DAS Cikapundung di Desa Dago adalah upaya masyarakat dalam menjaga dan melestarikan DAS .Penelitian ini bertujuan untuk mengetahui tingkat partisipasi masyarakat di Desa Dago kegiatan pengelolaan daerah aliran sungai Cikapundung, dan faktor-faktor yang berhubungan dengan sikap DAS manajemen, pengelolaan daerah aliran sungai dan hubungan sikap dengan tingkat partisipasi masyarakat. Data dianalisis dengan menggunakan uji korelasi Rank Spearman dan Chi-square. Hasil penelitian ini menunjukkan bahwa tingkat partisipasi masyarakat di Desa Dago tergolong cukup baik, dan kecenderungan sikap masyarakat di Desa Dago merupakan komponen utama untuk mendorong berpartisipasi dalam pengelolaan daerah aliran sungai kegiatan.

Kata kunci: partisipasi, perilaku masyarakat

\section{Pendahuluan}

Kondisi beberapa daerah aliran sungai (DAS) telah dinilai sangat memprihatinkan, sehingga sangat dibutuhkan pengelolaan DAS untuk menjaga keberlangsungan dan keberlanjutannya. Keputusan Menteri Kehutanan No.SK.328/MenhutII/2009 disebutkan bahwa sebesar 108 DAS dalam kondisi kritis yang memerlukan prioritas penanganan (Litbang, 2010). Menurut Undang-Undang Republik Indonesia No. 7 Tahun 2004, DAS adalah suatu wilayah daratan yang merupakan satu kesatuan dengan sungai dan anak-anak sungainya, yang berfungsi menampung, menyimpan, dan mengalirkan air yang berasal dari curah hujan ke danau atau ke laut secara alami, yang batas di darat merupakan pemisah topografi dan batas di laut sampai dengan daerah perairan yang masih terpengaruh aktivitas darat. Definisi ini menunjukan adanya keterkaitan yang saling mempengaruhi antar kawasan yang berada di bagian hulu, tengah dan hilir sungai.

Berdasarkan Undang-Undang Republik
Indonesia No. 22 Tahun 1999 tentang pemerintah daerah yang menyatakan bahwa pemerintah pusat memberikan kewenangan kepada pemerintah daerah untuk mengatur daerahnnya masing-masing.Hal ini sangat mempengaruhi ketidaksepadanan pengelolaan karena setiap wilayah administrasi berusaha untuk mencapai pertumbuhan ekonomi tanpa memperhatikan lingkungan sekitarnya. Efek dari pembangunan tersebut menghasilkan dampak negatif terhadap wilayah administrasi lainnya, khususnya untuk kawasan hilir sungai.Oleh karena itu, diperlukan sinergitas pengelolaan DAS antar wilayah administrasi dan peran penting Stakeholder (masyarakat, pemerintah dan swasta) dalam pengambilan keputusan yang lebih mengutamakan keberlanjutan.

Menurut Tampubolon (2007), permasalahan lingkungan hidup disebabkan oleh adanya ketidakharmonisan antara aktivitas ekonomi dengan eksistensi dan terbatasnya kapasitas sumberdaya alam dalam upaya memenuhi kebutuhan manusia. Hal ini disebabkan oleh laju pertumbuhan penduduk 
dan pembangunan di segala sektor yang tinggi sehingga menyebabkan menurunnya daya dukung wilayah. Terutama perubahan tata guna lahan dan konversi hutan (land use change and forestry). Kerusakan ekosistem DAS terutama disebabkan oleh aktivitas manusia yang tidak mempedulikan akibat dari kegiatan tersebut. Kerusakan yang diakibatkan oleh kegiatan manusia tersebut tentunya membutuhkan perbaikan, untuk itu perbaikan terhadap kerusakan lingkungan DAS sangat bergantung pula pada aktivitas manusia yang sebenarnya dapat diatur melalui swadaya masyarakat yang sadar akan pentingnya aksi penyelamatan DAS.

Pengelolaan sumberdaya alam pada suatu DAS, perlu dikelola secara berkelanjutan dengan menyeimbangkan aspek ekonomi, ekologis dan sosial. Pada kenyataanya keseimbangan ini tidak terjadi karena pemanfaatan sumberdaya alam DAS lebih berorientasi pada aspek ekonomi sehingga mengakibatkan menurunnya kualitas DAS di berbagai wilayah di Indonesia (Karyana, 2007).Salah satu langkah awal untuk mengatasi kerusakan DAS yang semakin parah adalah dengan membentuk gerakan masyarakat untuk bersama-sama menjaga dan melestarikan ekosistem DAS (Halimatusadiah et al., 2012). Gerakan masyarakat dalam menjaga dan melestarikan DAS dapat dilihat pada masyarakat di Kelurahan Dago, Kecamatan Coblong, Bandung, Jawa Barat yang membentuk komunitas-komunitas yang peduli terhadap Cikapundung dan mengajak masyarakat sekitar untuk ikut berpartisipasi dalam kegiatankegiatan yang dilaksanakan untuk penyelamatan DAS. Dengan demikian, tujuan penelitian ini adalah : 1) menganalisis tingkat partisipasi dan faktorfaktor yang berhubungan dengan sikap masyarakat Kelurahan Dago, Bandung, Jawa Barat terhadap kegiatan pengelolaan DAS, 2) menganalisis hubungan antara intensitas sikap masyarakat dengan tingkat partisipasinya terhadap kegiatan pengelolaan DAS di
Kelurahan Dago.

\section{Metode Penelitian}

Variabel independent yang digunakan dalam penelitian ini adalah faktor eksternal yang terdiri dari :1) dukungan(peran) tokohmasyarakat, 2) tingkat dukungan masyarakat sekitar, 3) tingkat ketersediaan fasilitas, dan 4) sumber informasi/komunikasi, dan factor internal yang terdiri dar: 1) umur, 2) jenis pekerjaan, 3) tingkat pendapatan, dan 4) tingkat pendidikan, sedangkan faktor eksternal yang digunakan dalam penelitian ini yaitu 1) Intensitas sikap pengelolaan DAS, dan 2)tingkat partisipasi masyarakat.

Penelitian ini dilakukan Penelitian ini dilaksanakan di RW 03, RW 12 dan RW13 Kelurahan Dago, Kota bandung, Provinsi Jawa Barat. Waktu penelitian dilaksanakan pada bulan April sampai dengan Juni. Populasi dalam penelitian ini adalah masyarakat yang tinggal di Kelurahan Dago, Kota Bandung, Jawa Barat dan unit analisis dalampenelitian ini adalah individu yang berjumlah 70 responden. Analisis data penelitian ini menggunakan analisis statistic inferensia. Uji statistik yang digunakan yaitu 1) Chi-square, dan 2) rank spearman.

\section{Hasil dan Pembahasan}

\section{Deskripsi Kegiatan Pengelolaan DAS Cikapundung, di Kelurahan Dago}

Kegiatan pengelolaan DAS di Kelurahan Dago berawal pada tahun 2010.Hal ini bermula dari kepedulian masyarakat terhadap DAS Cikapundung yang semakin memprihatinkan.Oleh karena itu, Masyarakat kemudian membentuk komunitas yang peduli Sungai Cikapundung. Sampai saat ini komunitas terbentuk sebanyak 52 komunitas yang tersebar di

Tabel 1 Distibusi Responden Menurut Tingkat Umur di Kelurahan Dago, Tahun 2013

\begin{tabular}{ccc}
\hline Selang umur (Tahun) & Kategori & Persentase \\
\hline $14-19$ & Rendah & $\mathbf{( \% )}$ \\
$20-46$ & Sedang & 8,60 \\
$47 \leq$ & Tinggi & 78,60 \\
\hline Total & & 12,90 \\
\hline
\end{tabular}


Jurnal Penyuluhan, Maret 2014 Vol. 10 No. 1

Tabel 2 Distribusi Responden Menurut Jenis Pekerjaan di Kelurahan Dago, Tahun 2013

\begin{tabular}{lc}
\hline \multicolumn{1}{c}{ Jenis pekerjaan } & Persentase \\
& $(\mathbf{\%})$ \\
\hline Ibu rumah tangga & 22,90 \\
Supir & 2,90 \\
Wiraswasta & 17,10 \\
Pengangguran & 12,90 \\
Pelajar & 14,30 \\
Karyawan swasta & 5,70 \\
Buruh & 5,70 \\
Lain-lain & 18,30 \\
\hline \multicolumn{1}{c}{ Total } & 100,00 \\
\hline
\end{tabular}

sepanjang kawasan yang di aliri Sungai Cikapundung. Komunitas-komunitas ini sangat berperan penting dalam mengajak masyarakat untuk mau berpartisipasi pada kegiatan pengelolaan DAS. Penelitian ini lebih menganalisis masyarakat. Masyarakat Kelurahan Dago yang ikut pada kegiatan pengelolaan DAS lebih didominasi oleh masyarakat yang tinggal di bantaran Sungai Cikapundung karena berdasarkan informasi yang didapat dari warga setempat, menyatakan bahwa apabila DAS Cikapundung tidak diperbaiki, dan dipelihara maka akan menjadi ancaman, terutama bagi warga yang tinggal di sekitar sungai. Sedangkan untuk warga Kelurahan Dago yang tinggal jauh dari kawasan DAS, bisa dikatakan hampir tidak pernah ikut berpartisipasi terhadap kegiatan pengelolaan DAS Cikapundung, hal ini disebabkan oleh, lokasi kegiatan yang cukup jauh dan cukup terjal.Selain dari masyarakat, mahasiswa juga turut dalam kegiatan pengelolaan DAS.

Kegiatan pengelolaan DAS yang dilakukan oleh masyarakat di bantaran Sungai Cikapundung, Kelurahan Dago yaitu, pertemuan-pertemuan yang membahas tentang perencanaan kegiatan, mengangkut sampahyangada di daerahbantaran sungai dan di sungai, penghijauan, serta melakukan penyuluhan, akan tetapi masyarakat kurang merespon kegiatan penyuluhan tersebut, karena masyarakat lebih tertarik terhadap tindakan nyata dan menurut pernyataan beberapa warga, bahwa kegiatan penyuluhan ini hanya diikuti oleh anggota komunitas, dan kegiatan pemantauan dengan menyusuri sungai untuk melihat proses berjalannya kegiatan. Selain itu, Sungai Cikapundung sering dijadikan sebagai tempat wisata arum jeram dan sarananya disediakan oleh komunitas peduli Cikapundung.Wisata arum jeram ini diberlakukan agar masyarakat tidak lagi membuang sampah ke area sungai.Pengelolaan DAS Cikapundung menggunakan cara-cara konvensional tanpa menggunakan teknologi modern, alat-alat yang digunakan untuk mengangkut sampah dan penghijauan dibawa oleh masyarakat dari rumahnya masing-masing. Kegiatan ini dilakukan seminggu sekali pada hari minggu, sehingga semua warga dapat ikut pada kegiatan ini.

Pengelolaan kawasan DAS menghadapi berbagai masalah yang amat kompleks. Menurut Sangadji (2010), salah satu masalah yang dihadapi adalah

Tabel 3 Distribusi Responden Menurut Tingkat Pendapatan di Kelurahan Dago Tahun 2013

\begin{tabular}{ccc}
\hline Jumlah pendapatan & Kategori & $\begin{array}{c}\text { Persentase } \\
(\mathbf{\%})\end{array}$ \\
\hline Rp $0.00-\operatorname{Rp~} 72.988$ & Rendah & 30,00 \\
$\operatorname{Rp~} 72.989-\operatorname{Rp~} 1,499,011$ & Sedang & 48,60 \\
$\operatorname{Rp~} 1.499 .012-\operatorname{Rp~} 3.000 .000$ & Tinggi & 21,40 \\
\hline Total & & 100,00 \\
\hline
\end{tabular}


Tabel 4 Distribusi Responden Menurut Tingkat Pendidikan di Kelurahan Dago Tahun 2013

\begin{tabular}{|c|c|}
\hline Tingkat pendidikan & $\begin{array}{c}\text { Persentase } \\
(\%)\end{array}$ \\
\hline Tidak sekolah & 2,90 \\
\hline $\mathrm{SD} / \mathrm{SMP}$ & 58,60 \\
\hline SMA/perguruan tinggi & 38,50 \\
\hline Total & 100,00 \\
\hline
\end{tabular}

terbatasnya kemampuan pemerintah dalam menjaga keutuhan ekosistemnya sehingga menjadi sumberdaya alam yang terbuka (open acces), dan kondisi ini sering dimanfaatkan pihak yang tidak bertanggungjawab (free rider) bagi keuntungan ekonomi jangka pendek dengan mengorbankan keutuhan ekosistem. Seperti yang dihadapi oleh masyarakat dalam ikut berpartisipasi pada kegiatan pengelolaan DAS adalah masih banyaknya masyarakat yang membuang sampah rumah tangganya ke sungai karena belum tersedianya TPS di sekitar DAS dan adanya lembaga swasta maupun lembaga pemerintah yang membuang limbahnya ke Sungai Cikapundung. Selain itu, DAS Cikapundung melintasi tiga wilayah administrasi, yaitu Kota Bandung, Kabupaten Bandung dan Kabupaten Bandung Barat, namun hanya masyarakat Kota Bandung yang aktif dalam menjaga dan melestarikan DAS Cikapundung.

\section{Faktor-Faktor yang Berhubungan dengan Intensitas Perilaku Masyarakat terhadap Kegiatan Pengelolaan DAS}

\section{Faktor Internal Masyarakat}

Faktor internal masyarakat dalam penelitian ini terbagi atas lima bagian, yaitu: umur, jenis pekerjaan, tingkat pendapatan, tingkat pendidikan dan juga jumlah tanggungan keluarga.

\section{Umur}

Sebagian besar masyarakat yang mengikuti kegiatan pengelolaan DAS berada pada selang umur 20 sampai 46 tahun sebesar $60 \%$, sehingga dalam pengembangankegiatan pengelolaan DAS perluadanya perhatian pada selang umur ini sehingga kegiatan pengelolaan DAS dapat mengalami keberlanjutan. Secara rinci dapat dilihat pada Tabel 1.

Umur seseorang berpotensi berhubungan dengan intensitas perilaku pengelolaan DAS dalam memberikan kontribusi pada kegiatan pengelolaan DAS, karena semakin tinggi umur seseorang maka intensitas perilaku masyarakat untuk mau terlibat dalam kegiatan pengelolaan DAS akan semakin tinggi. Menurut Rakhmat (2003), menjelaskan bahwa kelompok orang tua menimbulkan pola perilaku yang pasti berbeda dengan kelompok anakanak muda. Selain itu, menurut Wahyudin (2004), umur seseorang dapat mempengaruhi fungsi biologis dan psikologis individu.

\section{Jenis Pekerjaan}

Masyarakat di Kelurahan Dago memiliki

Tabel 5 Distribusi Responden Menurut Pernyataan Responden tentang Peran Tokoh Masyarakat di Kelurahan Dago, Tahun 2013

\begin{tabular}{lc}
\hline \multicolumn{1}{c}{ Dukungan (peran) tokoh masyarakat } & Persentase (\%) \\
\hline Rendah & 22,90 \\
Sedang & 58,60 \\
Tinggi & 18,60 \\
\hline Total & 100,00 \\
\hline
\end{tabular}


Tabel 6 Tingkat dan Persentase Dukungan Masyarakat Sekitar terhadap Kegiatan Pengelolaan DAS di Kelurahan Dago, Tahun 2013

\begin{tabular}{lc}
\hline \multicolumn{1}{c}{ Dukungan masyarakat sekitar } & Persentase \\
\hline Rendah & $\mathbf{( \% )}$ \\
Sedang & 14,30 \\
Tinggi & 70,00 \\
\hline Total & 15,70 \\
\hline
\end{tabular}

jenis pekerjaan yang beragam, diantaranya, ibu rumah tangga, supir, wiraswasta, pengangguran, pelajar, karyawan swasta, dan buruh.Secara rinci dapat dilihat pada Tabel 7.Jenis pekerjaan berpotensi memiliki hubungan dengan intensitas sikap pengelolaan DAS, karena jenis pekerjaan menentukan peluang waktu orang tersebut untuk turut berpartisipasi pada kegiatan pengelolaan DAS.

Berdasarkan Tabel 2 diketahui bahwa ibu rumah tangga memiliki peluang lebih tinggi dalam mengikuti kegiatan pengelolaan DAS karena bekerja pada lingkup domestik, dibandingkan dengan responden yang bekerja di luar rumah. Untuk itu, perlu adanya perhatian khusus terhadap ibu rumah tangga agar keberlanjutan kegiatan pengelolaan DAS tetap terjaga.

\section{Tingkat Pendapatan}

Secara umum pendapatan masyarakat di bantaran Sungai Cikapundung, Kelurahan Dago berkisar antara Rp 0.00 - Rp 3.000.000 per bulannya, dengan rata-rata pendapatan per bulannya sekitar Rp 786.000. Pendapatan masyarakat dengan kategori rendah sebesar $30 \%$, kategori sedang sebesar $48,60 \%$, dan kategori tinggi sebesar $21,40 \%$. Secara rinci dapat dilihat pada Tabel 3.
Pendapatan seseorang berpotensi memiliki hubungan dengan intensitas sikap kegiatan pengelolaan DAS, karena dengan tingkat pendapatan yang tinggi maka orang tersebut dapat turut berkontribusi pada dana yang bermanfaat untuk pengembangan kegiatan tersebut.

\section{Tingkat Pendidikan}

Tingkat pendidikan masyarakat di Kelurahan Dago, cukup beragam. Tingkat pendidikan masyarakat paling tinggi berada pada SD/SMP sebesar 58,60\%, dan SMA/perguruan tinggi sebesar 38,50\%. Tingkat pendidikan menggambarkan kemampuan seseorang dalam pengetahuan, kecenderungan sikap dan pengambilan keputusan untuk bertindak.Oleh karena itu, tingkat pendidikan berpotensi berhubungan dengan intensitas perilaku pengelolaan DAS pada masyarakat di Kelurahan Dago. Menurut Wahyudin (2004), tingkat pendidikan seseorang merupakan cerminan tingkat penguasaan terhadap suatu pengetahuan yang dapat dilihat pada perilakunya dalam hidup bermasyarakat. Selain itu, menurut Suprayitno (2011), menyatakan bahwa kualitas dan kekuatan suatu bangsa atau masyarakat bukan ditentukan oleh akumulasi kekayaan sumberdaya

Tabel 7 Distribusi Responden Menurut Pernyataan Responden tentang Dukungan Masyarakat Sekitar terhadap Kegiatan Pengelolaan DAS di Kelurahan Dago Tahun 2013

\begin{tabular}{lc}
\hline \multicolumn{1}{l}{ Ketersediaan fasilitas } & Persentase \\
& $\mathbf{( \% )}$ \\
\hline Rendah & 10,00 \\
Sedang & 61,40 \\
Tinggi & 28,60 \\
\hline Total & 100,00 \\
\hline
\end{tabular}


Tabel 8 Distribusi Responden Menurut Pernyataan Responden tentang Sumber Informasi dalam Pengelolaan DAS di Kelurahan Dago, Tahun 2013

\begin{tabular}{lc}
\hline \multicolumn{1}{c}{ Sumber informasi } & Persentase (\%) \\
\hline Rendah & 27,10 \\
Sedang & 58,60 \\
Tinggi & 14,30 \\
\hline Total & 100,00 \\
\hline
\end{tabular}

alam yang melimpah, tetapi bagaimana melahirkan SDM yang mampu mengelola dan memanfaatkan sumberdaya alam dengan baik, yang dapat diwujudkan melalui proses pendidikan. Data ini menunjukkan bahwa tingkat pendidikan masyarakat di Kelurahan Dago masih tergolong rendah, karena masih tingginya masyarakat yang tidak menyelesaikan pendidikan hingga tingkat SMA. Hal ini disebabkan, kesadaran pendidikan masyarakat dimasa lalu rendah, mereka menganggap pendidikan bukan merupakan hal yang penting, namun dengan adanya perkembangan zaman para orang tua mulai menyadari akan pentingnya pendidikan bagi anak-anak mereka. Selain itu, tingginya biaya pendidikan membuat para orang tua kesulitan untuk bisa menyekolahkan anak-anak mereka sampai ke jenjang perguruan tinggi.

\section{Faktor Eksternal Masyarakat}

Faktor eksternal dalam penelitian ini terbagi atas empat bagian, yaitu: dukungan (peran) tokoh masyarakat, dukungan masyarakat sekitar, tingkat ketersediaan fasilitas dan sumber informasi.

\section{Dukungan (Peran) Tokoh Masyarakat}

Sebagian besar masyarakat di Kelurahan Dago berpendapat bahwa Dukungan (peran) tokoh masyarakat dalam kegiatan pengelolaan DAS cukup memuaskan. Sekitar 22,60\% merasa masih kurangnya dukungan (peran) tokoh masyarakat, 58,60\% merasa dukungan (peran) tokoh masyarakat cukup memuaskan dan 18,60\% orang merasa sangat puas dengan dukungan (peran) tokoh masyarakat. Secara rinci dapat dilihat pada Tabel 5.

Oleh karena itu, dukungan (peran) tokoh masyarakat berpotensi berhubungan dengan intensitas sikap pengelolaan DAS pada masyarakat Kelurahan Dago, karena sebagai orang yang disegani dan dipercaya oleh masyarakat kiranya dapat melakukan perubahan yang ada dalam masyarakat dengan turut menghimbau masyarakat untuk turut serta dalam kegiatan pengelolaan DAS dan lebih penting lagi keikutsertaan tokoh masyarakat untuk turut berpartisipasi pada kegiatan tersebut.

\section{Dukungan Masyarakat Sekitar}

Dukungan masyarakat sekitar Kelurahan Dago terhadap kegiatan pengelolaan DAS dengan kategori rendah sebesar 14,30\%, kategori sedang sebesar tujuh puluh persen, dan kategori tinggi sebesar $15,70 \%$. Secara rinci dapat dilihat pada Tabel 6.Dukungan masyarakat sekitar lebih dilihat dari bagaimana masyarakat sekitar saling mendorong

Tabel 9 Distribusi Responden Menurut Tingkat Pengetahuan Responden di Kelurahan Dago, Tahun 2013

\begin{tabular}{lc}
\hline \multicolumn{1}{c}{ Tingkat pengetahuan } & $\begin{array}{c}\text { Persentase } \\
(\mathbf{\%})\end{array}$ \\
\hline Rendah & 8,60 \\
Sedang & 0,00 \\
Tinggi & 91,40 \\
\hline Total & 100,00 \\
\hline
\end{tabular}


Tabel 10 Distribusi Responden Menurut Kecenderungan Sikap Responden di Kelurahan Dago, Tahun 2013

\begin{tabular}{lc}
\hline \multicolumn{1}{r}{ Kecenderungan sikap } & Persentase \\
& $\mathbf{( \% )}$ \\
\hline Rendah & 34,30 \\
Sedang & 34,30 \\
Tinggi & 31,40 \\
\hline Total & 100,00 \\
\hline
\end{tabular}

dalam berpartisipasi pada kegiatan pengelolaan DAS, karena semakin tinggi dukungan masyarakat sekitar maka akan berhubungan dengan intensitas perilaku masyarakat di bantaran Sungai Cikapundung, Kelurahan Dago terhadap kegiatan pengelolaan DAS.

\section{Tingkat Ketersediaan Fasilitas}

Tingkat ketersediaan fasilitas dengan kategori rendah sebesar sepuluh persen, kategori sedang sebesar $61,40 \%$ dan kategori tinggi sebesar $28,60 \%$. Tingkat ketersediaan fasilitas di Kelurahan Dago paling banyak berada pada kategori sedang. Hal ini disebabkan, warga harus membawa alat sendiri dari rumahnya untuk kegiatan pengelolaan DAS, namun warga merasa tidak keberatan dengan hal tersebut. Tingkat ketersediaan fasilitas masyarakat dalam mengelola DAS Cikapundung berpotensi berhubungan dengan intensitas perilaku pengelolaan DAS, karena tingkat ketersediaan fasilitas yang tinggi akan mendorong masyarakat di Kelurahan Dago untuk aktif dalam kegiatan pengelolaan DAS.

\section{Sumber Informasi}

Sumber informasi dengan kategori rendah sebesar $27,10 \%$, kategori sedang sebesar $58,60 \%$, dan kategori tinggi sebesar $14,30 \%$. Sebesar $58,60 \%$ masyarakat menganggap bahwa sumber informasi tentang pengelolaan DAS cukup baik. Sumber informasi berpotensi berhubungan dengan intensitas perilaku masyarakat terhadap pengelolaan DAS, karena semakin tinggi penyebaran informasi tentang pengelolaan DAS maka akan mendorong masyarakat untuk turut serta dalam kegiatan pengelolaan DAS, bukan hanya masyarakat yang tinggal di bantaran Sungai saja yang terlibat dalam pengelolaan DAS melainkan masyarakat di seluruh Kelurahan Dago. Menurut Bungin (2009), menyatakan bahwa sumber informasi adalah seseorang atau institusi yang memiliki bahan informasi (pemberitaan) untuk disebarkan kepada masyarakat luas. Sumber informasi bisa berupa orang-orang yang ada di lingkungan sekitar, seperti: tokoh masyarakat, masyarakat sekitar (tetangga), anggota keluarga, anggota komunitas dan melalui media televisi atau radio komunitas.

\section{Intensitas Perilaku Pengelolaan DAS}

Intensitas perilaku pengelolaan DAS terbagi atas tiga bagian, yaitu: tingkat pengetahuan, kecenderungan sikap dan tingkat keterampilan.

\section{Tingkat Pengetahuan}

Tingkat pengetahuan masyarakat di Kelurahan Dago sangat tinggi. Hal ini dapat dilihat pada Tabel

Tabel 11 Distribusi Responden Menurut Kecenderungan Bertindak Responden di Kelurahan Dago, Tahun 2013

\begin{tabular}{|c|c|}
\hline Tingkat keterampilan & $\begin{array}{c}\text { Persentase } \\
(\%)\end{array}$ \\
\hline Rendah & 18,60 \\
\hline Sedang & 55,70 \\
\hline Tinggi & 25,70 \\
\hline Total & 100,00 \\
\hline
\end{tabular}


Tabel 12 Hubungan Faktor Internal dengan Intensitas Perilaku Pengelolaan DAS

\begin{tabular}{llcc}
\hline \multicolumn{1}{c}{ Faktor internal } & \multicolumn{1}{c}{$\begin{array}{c}\text { Intensitas perilaku } \\
\text { pengelolaan DAS }\end{array}$} & $\begin{array}{c}\text { Correlation } \\
\text { coefficient (rs) }\end{array}$ & P-value \\
\hline Umur & Tingkat pengetahuan & $-0,092$ & 0,450 \\
& Kecenderungan sikap & 0,004 & 0,974 \\
Tingkat pendapatan & Tingkat keterampilan & $-0,288^{*}$ & 0,016 \\
& Kecenderungan sikap & 0,110 & 0,366 \\
& Tingkat keterampilan & 0,091 & 0,454 \\
Tingkat pendidikan & Tingkat pengetahuan & 0,012 & 0,043 \\
& Kecenderungan sikap & $0,243 *$ & 0,830 \\
& Tingkat keterampilan & 0,026 & 0,724 \\
& Tingkat pengetahuan & $-0,043$ & 0,286 \\
& Kecenderungan sikap & 20,872 & 0,126 \\
\hline
\end{tabular}

Keterangan: $*=$ signifikan pada taraf nyata $\alpha=0,05$

9 yang menunjukkan bahwa tingkat pengetahuan dengan kategori tinggi didapatkan sebesar $91,40 \%$, tingkat pengetahuan dengan kategori rendah didapatkan $8,60 \%$, sedangkan tidak terdapat jumlah orang pada tingkat pengetahuan sedang.

Data ini menunjukan, bahwa hampir seluruh masyarakat di Kelurahan Dago memiliki tingkat pengetahuan yang tinggi walaupun memiliki latar belakang yang berbeda-beda, baik dari umur, jenis pekerjaan, tingkat pendapatan, tingkat pendidikan dan jumlah tanggungan dalam keluarga. Tingkat pengetahuan yang tinggi ini berpotensi berhubungan dengan tingkat partisipasi warga terhadap kegiatan pengelolaan DAS, karena dengan tingkat pengetahuan yang tinggi pada masyarakat di kelurahan Dago akan mendorong masyarakat untuk mau berpartisipasi pada kegiatan pengelolaan DAS.

\section{Kecenderungan Sikap}

Kecenderungan sikap masyarakat di Kelurahan Dago cukup bervariasi terhadap kegiatan pengelolaan DAS. Kecenderungan sikap dengan kategori rendah sebesar 34,30\%, kategori sedang sebesar 34,30\% dan, kategori tinggi sebesar $31,40 \%$. Secara rinci dapat dilihat pada Tabel 10.

Kecenderungan sikap berpotensi berhubungan dengan partisipasi warga terhadap kegiatan pengelolaan DAS. Kecenderungan sikapyang diukurdalampenelitian ini adalah bagaimana respon dari masyarakat tentang kegiatan-kegiatan yang apabila akan dilaksanakan atau diadakan di Kelurahan Dago tentang pengelolaan DAS Cikapundung. Sikap yang positif masyarakat terhadap sesuatu hal memungkinkan masyarakat untuk berperilaku tetapi tidak semua sikap positif dapat membuat seseorang berperilaku. Data Pada Tabel 15 menunjukkan tidak ada perbedaan yang signifikan antara ketiga kategori ini namun kecenderungan sikap yang ada pada masyarakat di Kelurahan Dago cukup baik tentang kegiatan pengelolaan DAS karena masyarakat mulai menyadari akan pentingnya menjaga keberlanjutan dan juga kelestarian wilayah disekitar aliran DAS Cikapundung.

\section{Tingkat Keterampilan}

Tingkat keterampilan digunakan untuk mengukur tingkat kesulitan dari masyarakat dalam melakukan kegiatan pengelolaan DAS. Tingkat keterampilan dengan kategori rendah sebesar 18,60\%, kategori sedang sebesar $55,70 \%$, dan kategori tinggi sebesar $25,70 \%$. Secara rinci dapat dilihat pada Tabel 11.

Sebagian besar $(55,70 \%)$ masyarakat di Kelurahan Dago berkategori sedang. Hal ini disebaban oleh beberapa fasilitas pengelolaan DAS yang belum 
Tabel 13 Hubungan Faktor Eksternal dengan Intensitas Perilaku Pengelolaan DAS

\begin{tabular}{llcc}
\hline \multicolumn{1}{c}{ Faktor eksternal } & \multicolumn{1}{c}{$\begin{array}{c}\text { Intensitas perilaku } \\
\text { pengelolaan DAS }\end{array}$} & Correlation coefficient & P-value \\
\hline $\begin{array}{l}\text { Dukungan (peran) tokoh } \\
\text { masyarakat }\end{array}$ & Tingkat pengetahuan & 0,141 & 0,243 \\
& Kecenderungan sikap & 0,159 & 0,189 \\
& Tingkat keterampilan & $-0,214$ & 0,076 \\
Dukungan masyarakat sekitar & Tingkat pengetahuan & $-0,086$ & 0,478 \\
& Kecenderungan sikap & $0,290^{*}$ & 0,015 \\
Tingkat ketersediaan fasilitas & Tingkat keterampilan & $0,355^{* *}$ & 0,003 \\
& & & \\
& Tingkat pengetahuan & 0,076 & 0,531 \\
& Kecenderungan sikap & 0,102 & 0,400 \\
Sumber informasi/komunikasi & Tingkat keterampilan & $0,321^{* *}$ & 0,007 \\
& & & 0,135 \\
& Tingkat pengetahuan & 0,181 & 0,033 \\
& Kecenderungan sikap & $0,256^{*}$ & 0,001 \\
\hline
\end{tabular}

\begin{tabular}{ll}
\hline Keterangan: & $*=$ signifikan pada taraf nyata 0,05 \\
& $* *=$ signifikan pada taraf nyata 0,01
\end{tabular}

ada atau tidak tersedia pada lingkungan di sekitar bantaran sungai, seperti: Tempat Pembuangan Sampah, penyediaan bibit, alat/keterampilan untuk mendaur ulang sampah dan pembuatan septic tank komunal, sehingga masyarakat yang tinggal di bantaran Sungai Cikapundung, Kelurahan Dago mengalami kesulitan dalam menjaga lingkungan sekitar agar tetap bersih.

\section{Hubungan Faktor Internal Masyarakat dengan Intensitas Perilaku Pengelolaan DAS}

Hubungan faktor internal masyarakat di
Kelurahan Dago dengan intensitas perilaku pengelolaan DAS diuji dengan menggunakan uji korelasi rank spearman untuk variabel ordinal (umur dan tingkat pendapatan) dan uji korelasi chi square untuk variabel nominal (jenis pekerjaan). Berdasarkan hasil pengolahan data, variabel yang memiliki hubungan nyata (signifikan pada taraf nyata $\alpha=0,05$ ) pada faktor internal masyarakat adalah umur dengan kecenderungan bertindak, dan tingkat pendidikan dengan tingkat pengetahuan. Umur dengan kecenderungan bertindakmemiliki korelasi koefisien -0,288. Artinya, umur dengan kecenderungan bertindak berhubungan negatif dengan keeratan hubungan

Tabel 14 Distribusi Responden Menurut Tingkat Partisipasi Perencanaan Kegiatan Pengelolaan DAS Cikapundung di Kelurahan Dago, Tahun 2013

\begin{tabular}{lcc}
\hline & Perencanaan kegiatan & Persentase \\
& $(\mathbf{\%})$ \\
\hline Rendah & 30,00 \\
Sedang & 35,70 \\
Tinggi & 34,30 \\
\hline \multirow{2}{*}{ Total } & 100,00 \\
\hline
\end{tabular}


Tabel 15 Distribusi Responden Menurut Tingkat Partisipasi Pelaksanaan Kegiatan Pengelolaan DAS Cikapundung di Kelurahan Dago, Tahun 2013

\begin{tabular}{lc}
\hline \multicolumn{1}{c}{ Pelaksanaan kegiatan } & Persentase \\
\hline Rendah & $\mathbf{( \% )}$ \\
Sedang & 15,70 \\
Tinggi & 65,70 \\
\hline Total & 18,60 \\
\hline
\end{tabular}

rendah sekali; lemah sekali. Hal ini menunjukkan, bahwa semakin tinggi umur maka kecenderungan bertindak seseorang juga semakin tinggi, namun yang terjadi adalah umur yang semakin tinggi akan menyebabkan seseorang mengalami kesulitan untuk ikut serta pada kegiatan pengelolaan DAS. Hubungan tingkat pendidikan dengan tingkat pengetahuan diperoleh koefisien korelasi 0,243. Artinya, tingkat pendidikan dengan tingkat pengetahuan berhubungan positif dengan keeratan hubungan rendah tetapi pasti.Hal ini menunjukkan, bahwa semakin tinggi tingkat pendidikan seseorang maka tingkat pengetahuan orang tersebut juga semakin tinggi. Selain dari variabel yang berhubungan nyata ada juga variabel yang tidak berhubungan nyata (Tabel 12).

1. Umur terhadap tingkat pengetahuan masyarakat. Hal ini dapat dilihat kembali pada Tabel 9 yang menunjukkan bahwa hampir seluruh masyarakat $(91,40 \%)$ memiliki tingkat Umur masyarakat ternyata tidak berkaitan pengetahuan yang tinggi walaupun dari latar belakang usia yang berbeda-beda. Umur masyarakat juga ternyata tidak berkaitan dengan kecenderungan sikap masyarakat terhadap kegiatan pengelolaan DAS. Hal ini menunjukkan, bahwa dengan variasi umur berapapun setiap orang dapat memiliki kecenderungan sikap untuk mau turut berpartisipasi pada kegiatan pengelolaan DAS, tidak terbatas hanya pada orang dewasa saja.

2. Tingkat pendapatan masyarakat ternyata tidak berkaitan terhadap intensitas perilaku pengelolaan DAS. Hal ini disebabkan, dengan murahnya biaya untuk mengakses informasi dengan internet sehingga dapat dijangkau oleh masyarakat walaupun berpendapatan rendah. Selain itu, meskipun ada masyarakat di Kelurahan Dago yang memiliki tingkat pendapatan tinggi namun kecenderungan masyarakat untuk mau berswadaya dalam dana masih sangat rendah, dan juga memiliki kesulitan dalam menjaga keberlangsungan DAS, karena kebutuhan ekonomi yang semakin meningkat.

3. Jenis pekerjaan ternyata tidak berkaitan dengan seluruh komponen intensitas pengelolaan DAS. Hal ini disebabkan oleh, hampir seluruh masyarakat di Kelurahan Dago memiliki tingkat pengetahuan yang tinggi walaupun dari latar belakang jenis pekerjaan yang berbeda, dan kegiatan pengelolaan DAS selalu dilaksanakan pada hari libur, yaitu hari minggu, sehingga tidak mengganggu jadwal pekerjaan masyarakat.

4. Tingkat pendidikan ternyata tidak berkaitan dengan kecenderungan sikap dan kecenderungan bertindak. Hal ini disebabkan karena tidak tersedianya sarana dan prasarana penunjang dalam menjaga

Tabel 16 Distribusi Responden Menurut Tingkat Partisipasi Pemantauan dan Evaluasi Kegiatan Pengelolaan DAS Cikapundung di Kelurahan Dago, Tahun 2013

\begin{tabular}{lc}
\hline \multicolumn{1}{c}{ Pemantauan dan evaluasi kegiatan } & Persentase \\
\hline Rendah & $\mathbf{( \% )}$ \\
Sedang & 30,00 \\
Tinggi & 42,90 \\
\hline Total & 27,10 \\
\hline
\end{tabular}


Tabel 17 Distribusi Responden Menurut Tingkat Partisipasi Pemanfaatan Hasil Kegiatan Pengelolaan DAS Cikapundung di Kelurahan Dago, Tahun 2013

\begin{tabular}{lc}
\hline \multicolumn{1}{c}{ Pemanfaatan hasil kegiatan } & Persentase \\
\hline Rendah & $(\mathbf{\% )}$ \\
Sedang & 37,10 \\
Tinggi & 45,70 \\
\hline Total & 17,10 \\
\hline
\end{tabular}

kebersihan DAS, seperti tempat sampah, septictank komunal dan lain-lain sehingga menyebabkan masyarakat kurang tertarik untuk ikut serta dalam kegiatan pengelolaan DAS

\section{Hubungan Faktor Eksternal dengan Intensitas Perilaku Pengelolaan DAS}

Faktor-faktor yang berasal dari luar individu, yaitu: dukungan (peran) tokoh masyarakat, tingkat dukungan masyarakat sekitar, tingkat ketersediaan fasilitas dan sumberinformasi/komunikasi.Ujianalisis yang digunakan untuk melihat hubungan antara faktor eksternal dengan intensitas sikap pengelolaan DAS adalah uji korelasi rank spearman. Uji korelasi rank spearman digunakan karena merupakan variabel dengan skala pengukuran ordinal. Berdasarakan hasil yang didapat dari pengolahan data, faktor eksternal yang memiliki hubungan sangat nyata (signifikan pada taraf $\alpha=0,01$ ), yaitu dukungan masyarakat sekitar dengan kecenderungan bertindak, tingkat ketersediaan fasilitas dengan kecenderungan bertindak, dan sumber informasi dengan kecenderungan bertindak. Dukungan masyarakat sekitar dengan kecenderungan bertindak memiliki korelasi koefisien 0,355.Artinya, dukungan masyarakat sekitar dengan tingkat keterampilan berhubungan positif dengan keeratan hubungan rendah tetapi pasti.Hal ini menunjukkan, bahwa dukungan dari masyarakat sekitar memberi dampak terhadap sikap masyarakat yang tidak ikut berpartisipasimerasa tidak nyaman apabila membuang sampah ke sungai.Tingkat ketersediaan fasilitas dengan kecenderungan bertindak memiliki korelasi koefisien 0,321, artinya, tingkat ketersediaan fasilitas dengan kecenderungan bertindak berhubungan positif dengan keeratan hubungan rendah tetapi pasti. Hal ini menunjukkan, bahwa masyarakat, Kelurahan Dago, lebih khususnya bagi masyarakat yang tinggal di bantaran Sungai Cikapundung mengalami kesulitan untuk membuang sampahkarena untuk kawasan DAS tidak tersedia tempat pembuangan sampah yang memadai sehingga masyarakat yang tinggal di bantaran Sungai Cikapundung masih ada yang sering membuang sampah ke sungai. Sumber informasi dengan kecenderungan bertindak yang memiliki korelasi koefisien 0,402. Artinya, sumber informasi dengan kecenderungan bertindak berhubungan positif dengan keeratan hubungan yang cukup berarti.Hal ini menunjukkan, bahwa informasi yang diperoleh tentang kegiatan pengelolaan DAS dapat meningkatkankeinginan individu untuk terlibat dalam kegiatan tersebut.

Faktor eksternal yang memiliki hubungan nyata (signifikan pada taraf $\alpha=0,05$ ), yaitu dukungan masyarakatsekitar dengan kecenderungan sikap, dan sumberinformasi/komunikasi dengan kecenderungan sikap. Dukungan masyarakat sekitar memiliki korelasi koefisien 0,290. Artinya, dukungan masyarakat dengan kecenderungan sikapberhubungan positifdengankeeratan hubungan rendah tetapi pasti.Hal ini menunjukkan, bahwa dukungan dari masyarakat sekitar dalam kegiatan pengelolaan memberi dampak pada sikap masyarakat yang tidak ikut berpartisipasi, merasa tidak nyaman apabila membuang sampah ke sungai.Sumber informasi/ komunikasi dengan kecenderungan sikap memiliki korelasi koefisien 0,256. Artinya, sumber informasi/ komunikasi berhubungan positif dengan keeratan hubungan rendah tetapi pasti. Hal ini menunjukkan, bahwa sumber informasi/komunikasi sangat penting untuk pembentukan sikap pada masyarakat di Kelurahan Dago dalam menjaga dan melestarikan lingkungan DAS ( Tabel 13).

Dukungan (peran) tokoh masyarakat ternyata tidak berkaitan dengan intensitas perilaku pengelolaan DAS. Hal ini menunjukkan, dalam hal kegiatan pengelolaan DAS yang lebih banyak berperan adalah 
Tabel 18 Hubungan Intensitas Sikap Pengelolaan DAS dengan Partisipasi Masyarakat dalam Kegiatan Pengelolaan DAS, Tahun 2013

\begin{tabular}{llcl}
\hline $\begin{array}{c}\text { Intensitas perilaku pengelo- } \\
\text { laan DAS }\end{array}$ & \multicolumn{1}{c}{ Partisipasi } & Correlation coefficient & P-value \\
\hline Tingkat pengetahuan & Perencanaan & 0,082 & 0,501 \\
Kecenderungan sikap & & $0,242^{*}$ & 0,043 \\
Kecenderungan bertindak & & $-0,113$ & 0,351 \\
Tingkat pengetahuan & Pelaksanaan & $-0,159$ & 0,188 \\
Kecenderungan sikap & & $0,237^{*}$ & 0,049 \\
Kecenderungan bertindak & & 0,147 & 0,224 \\
Tingkat pengetahuan & Evaluasi (pemantauan) & 0,122 & 0,316 \\
Kecenderungan sikap & & $0,299^{*}$ & 0,012 \\
Kecenderungan bertindak & & $-0,116$ & 0,338 \\
Tingkat pengetahuan & Pemanfaatan & $-0,236^{*}$ & 0,049 \\
Kecenderungan sikap & & $0,257^{*}$ & 0,032 \\
Kecenderungan bertindak & & 0,134 & 0,270 \\
\hline Kerangan:
\end{tabular}

Keterangan: * = signifikan pada taraf nyata 0,05

komunitas dan masyarakat sekitar DAS Cikapundung, Kelurahan Dago. Dukungan masyarakat sekitar DAS Cikapundung, Kelurahan Dago ternyata tidak berkaitan dengan tingkat pengetahuan masyarakat. Hal ini menunjukkan, hampir seluruh masyarakat di Kelurahan Dago sudah memiliki tingkat pengetahuan yang tinggi. Tingkat ketersediaan fasilitas ternyata tidak berkaitan dengan tingkat pengetahuan masyarakat. Hal ini disebabkan karena masyarakat di Kelurahan Dago hampir seluruhnya memiliki tingkat pengetahuan yang tinggi tentang lingkungan hidup, dan tingkat ketersediaan fasilitas ternyata tidak berkaitan dengan kecenderungan sikap masyarakat di Kelurahan Dago. Hal ini menunjukkan, keterbatasan dalam penyediaan fasilitas pengelolaan DAS namun tidak menutup kemungkinan bagi masyarakat untuk ikut terlibat pada kegiatan pengelolaan DAS.

Sumber informasi ternyata tidak berkaitan dengan tingkat pengetahuan masyarakat di Kelurahan Dago. Hal ini menunjukkan, bahwa selain dari teknologi informasi yang semakin maju, pengetahuan seseorang juga bisa didapat dari berbagai pengalaman hidupnya.

\section{Tingkat Partisipasi Masyarakat terhadap Kegiatan Pengelolaan DAS Cikapundung di}

\section{Kelurahan Dago}

Partisipasimasyarakatdiukurberdasarkantahap partisipasi, yaitu tahap partisipasi pada perencanaan program, tahap partisipasi pada pelaksanaan kegiatan, tahap partisipasi pada pemantauan dan evaluasi kegiatan, dan tahap partisipasi pada pemanfaatan hasil kegiatan.Berdasarkan pada tahap-tahap partisipasi, dapat dilihat bahwa setiap tahap partisipasi masyarakat berada pada kategori sedang. Hal ini menunjukkan, bahwa tingkat partisipasi masyarakat di Kelurahan Dago tergolong cukup baik karena masyarakat mulai menyadari akan pentingnya untuk turut serta dalam kegiatan pengelolaan DAS guna menjaga keberlanjutan DAS. Oleh sebab itu, faktor internal dan eksternal individu sangat berkaitan dengan intensitas sikap individu untuk mau berpartisipasi pada seluruh tahap partisipasi.

\section{Tahap Perencanaan}

Masyarakat yang ikut berpartisipasi pada perencanaan kegiatan pengelolaan DAS dengan kategori rendah sebesar tiga puluh persen, kategori sedang sebesar 35,70\%, dan kategori tinggi sebesar 34,30\%. Secara rinci dapat dilihat pada Tabel 14 . 
Indikator yang digunakan pada tahap perencanaan adalah keikutsertaan masyarakat dalam pertemuanpertemuan yang membahas tentang rencana-rencana kegiatan pengelolaan DAS dan strategi-strategi yang akan di lakukan agar kegiatan pengelolaan DAS dapat tercapai secara maksimal. Data pada Tabel 14 menunjukkan bahwa cukup banyak masyarakat yang masih tergolong rendah untuk berpartisipasi pada perencanaan kegiatan, karena masyarakat lebih cenderung untuk mengikuti pelaksanaan kegiatan daripada mengikuti perencanaan kegiatan, terutama untuk kaum perempuan yang beranggapan bahwa untuk perencanaan kegiatan sebaiknya dilakukan oleh lakilaki saja sedangkan perempuan dan anak-anak hanya ikut pada pelaksanaan kegiatan, namun ada beberapa perempuan yang mengikuti perencanaan kegiatan dan itupun hanyalah perempuan yang termasuk pada anggota komunitas.

\section{Tahap Pelaksanaan Kegiatan}

Masyarakat di Kelurahan Dago yang turut berpartisipasi pada kegiatan pengelolaan DAS untuk kategori rendah sebesar $15,70 \%$ merupakan responden tidak setiap minggu ikut pada pelaksanaan kegiatan pengelolaan DAS, kategori sedang sebesar 65,70 persen merupakan responden hampir setiap minggu turut berpartisipasi dalam kegiatan pengelolaan DAS, dan kategori tinggi sebesar $18,60 \%$, yaitu responden setiap minggu hadir dalam kegiatan pengelolaan DAS. Secara rinci dapat dilihat pada Tabel 15. Indikator yang digunakan pada tahap pelaksanaan adalah seberapa sering masyarakat ikut dalam pelaksanaan kegiatan.

Tabel 15 menunjukkan bahwa keikutsertaan masyarakat di Kelurahan Dago, pada pelaksanaan kegiatan pengelolaan sungai cukup baik, karena masyarakat lebih cenderung mengikuti kegiatan pengelolaan DAS dari pada turut serta dalam perencanaan kegiatan.

\section{Tahap Pemantauan dan Evaluasi Kegiatan}

Pemantauan dan evaluasi kegiatan yang dilakukan oleh responden untuk kategori rendah sebesar 30,00\%, pada kategori ini responden yang paling dominan adalah ibu-ibu, anak-anak dan responden yang bukan anggota/pengurus komunitas, serta responden yang menganggap bahwa tahap pemantauan dan evaluasi kegiatan merupakan tugas dari anggota komunitas. Pemantauan dan evaluasi kegiatan dengan kategori sedang sebesar $42,90 \%$, yang sebagian besar respondennya merupakan anggota/ pengurus komunitas yang jarang ikut dalam tahap pemantauan dan evaluasi kegiatan.Kategori tinggi sebesar $17,10 \%$, hal ini disebabkan karena responden memiliki peranan penting dalam komunitas/pengurus komunitas, sehingga harus hadir dalam tahap ini. Secara rinci dapat dilihat pada Tabel 16.

Kegiatan pengelolaan DAS Cikapundung di Kelurahan Dago, pemantauan dan evaluasi tidak dilaksanakan dalam bentuk rapat, melainkan meninjau langsung ke lapangan, sehingga dapat melihat bagaimana masyarakat di Kelurahan Dago melakukan kegiatan penghijauan dan menyusuri sungai untuk mengangkut sampah yang ada di sungai maupun yang ada di bantaran sungai. Menurut Wahyudin (2004) menyatakan, bahwa dalam tahap pemantauan dan evaluasi sangat diperlukan pelibatan masyarakat agar masyarakat dapat melihat seberapa besar tingkat keberhasilan yang dicapai dalam program tersebut, dan apakah hasil yang diperoleh sudah sesuai dengan target yang telah direncanakan sebelumnya atau justru tidak sesuai dengan target.

\section{Tahap Pemanfaatan Hasil Kegiatan}

Pemanfaatan hasil kegiatan oleh masyarakat di Kelurahan Dago dengan kategori rendah sebesar $37,10 \%$ dan paling banyak responden pada kategori ini berada pada RW III dan RW XII, hal ini disebabkan karena tidak tersedia fasilitas pengelolaan DAS, seperti kerajinan dari sampah, dan tempat pembuangan sampah yang memadai, pada kategori sedang sebesar $45,70 \%$ dan paling banyak responden pada kategori ini berada pada RW XIII, begitu juga pada kategori tinggi sebesar $17,10 \%$, hal ini disebabkan karena pada RW XIII sudah tersedianya tempat pembuangan sampah yang memadai dan alat khusus yang digunakan untuk mengolah limbah. Secara rinci dapat dilihat pada Tabel 17.

Selain dari ketersediaan fasilitas pengelolaan DAS yang dapat memberikan manfaat dari kegiatan pengelolaan DAS Cikapundung di Kelurahan Dago, berdasarkan wawancara langsung, warga menyatakan bahwa dengan adanya kegiatan ini maka warga mendapatkan manfaat dengan menjadikan Sungai Cikapundung menjadi wahana wisata arum jeram dan kukuyaan (alat yang terbuat dari ban, digunakan 
untuk berenang), padahal sebelumnya air di Sungai Cikapundung tidak bisa digunakan sama sekali karena sudah sangat tercemar.

\section{Analisis Hubungan Intensitas Sikap Pengelolaan DAS Cikapundung dengan Partisipasi Masyarakat Kelurahan Dago dalam Kegiatan Pengelolaan DAS}

Hubungan intensitas sikap pengelolaan DAS Cikapundung dengan partisipasi masyarakat di Kelurahan Dagoyang menunjukkan hubungan nyata (signifikan pada taraf $\alpha=0,05$ ), yaitu kecenderungan sikap masyarakat dengan perencanaan kegiatan memiliki korelasi koefisien 0,242. Artinya, kecenderungan masyarakat berhubungan positif dengan perencanaan kegiatan dan memiliki keeratan hubungan rendah tetapi pasti. Hal ini menunjukkan, bahwa perlu adanya penyadaran kepada masyarakat akan pentingnya untuk turut serta dalam perencanaan kegiatan. Kecenderungan sikap masyarakat dengan pelaksanaan kegiatan memiliki korelasi koefisien 0,237.Artinya, kecenderungan sikap berhubungan positif dengan pelaksanaan kegiatan dan memiliki keeratan hubungan rendah tetapi pasti. Hal ini menunjukkan, bahwa perlu adanya penyadaran kepada masyarakat akan pentingnya untuk terlibat dalam kegiatan-kegiatan pengelolaan DAS. Kecenderungan sikap dengan pemantauan dan evaluasi kegiatan memiliki korelasi koefisien 0,299. Kecenderungan sikap berhubungan positif dengan pemantauan dan evaluasi kegiatan dan memiliki keeratan hubungan rendah tetapi pasti. Hal ini menunjukkan, bahwa perlu adanya penyadaran kepada masyarakat akan pentingnya terlibat dalam pemantauan dan evaluasi kegiatan.

Tingkat pengetahuan memilki korelasi koefisien $-0,236$. Tingkat pengetahuan berhubungan negatif dengan pemanfaatan hasil kegiatan dan memiliki keeratan hubungan rendah sekali; lemah sekali.Hal ini menunjukkan, semakin tinggi tingkat pengetahuan seseorang maka pemanfaatan hasil kegiatan yang bersifat merusak ataupun mencemari lingkungan semakin rendah, namun masih ada warga yang memanfaatkan hasil kegiatan ini dengan membuang sampah ke sungai padahal hampir semua warga memiliki tingkat pengetahuan yang tinggi tentang lingkungan hidup. kecenderungan sikap masyarakat dengan pemanfaatan hasil kegiatan memiliki korelasi koefisien 0,257. Artinya, kecenderungan sikap masyarakat berhubungan positif pemanfaatan hasil kegiatan, dan memiliki keeratan hubungan rendah tetapi pasti. Hal ini menunjukkan, bahwa perlu adanya penyadaran kepada masyarakat akan pentingnya terlibat dalam pemanfaatan hasil kegiatan dengan demikian semua masyarakat dapat merasakan manfaat dari kegiatan tersebut. Selain itu, intensitas perilaku pengelolaan DAS pada masyarakat di Kelurahan Dago yang tidak menunjukkan adanya hubungan nyata dengan partisipasi masyarakat (Tabel 18).

Tingkat pengetahuan dan kecenderungan bertindak tidak memiliki hubungan nyata dengan partisipasi masyarakat terhadap perencanaan kegiatan. Hal ini disebabkan, masyarakat di Kelurahan Dago menganggap bahwa perencanaan kegiatan hanya bisa dilakukan oleh pihak-pihak tertentu saja, seperti anggota komunitas dan tokoh masyarakat. Tingkat pengetahuan dan kecenderungan bertindak masyarakat di Kelurahan Dago ternyata tidak berkaitan dengan keikutsertaan masyarakat dalam pelaksanaan kegiatan, karena masyarakat di bantaran Sungai Cikapundung, Kelurahan Dago berpendapat bahwa kegiatan pengelolaan DAS merupakan kepentingan semua pihak. jadi dalam pelaksanaannya tidak dibatasi kepada orang-orang tertantu saja melainkan siapa saja dapat turut serta dalam kegiatan ini.

Tingkat pengetahuan masyarakat di Kelurahan Dago dan kecenderungan bertindak masyarakat di Kelurahan Dago ternyata tidak berkaitan dengan keikutsertaan masyarakat dalam kegiatan pemantauan (evaluasi) karena seperti pada perencanaan kegiatan, begitu juga yang terjadi terhadap kegiatan pemantauan (evaluasi), bahwa masyarakat menganggap bahwa pemantauan (evaluasi) kegiatan hanya merupakan tugas dari pihak-pihak tertantu saja. Kecenderungan bertindak masyarakat di Kelurahan Dago ternyata tidak berkaitan dengan keikutsertaan masyarakat dalam pemanfaatan hasil kegiatan pengelolaan DAS Cikapundung di Kelurahan Dago, karena dalam pemanfaatan hasil kegiatan terhadap DAS Cikapundung tidak bisa dimanfaatkan untuk konsumsi rumah tangga.

\section{Pengembangan Partisipasi Masyarakat dalam Kegiatan Pengelolaan DAS Cikapundung di Kelurahan Dago}

Partisipasi masyarakat terhadap pengelolaan DAS Cikapundung di Kelurahan Dago dapat ditingkatkan dengan memperbaiki intensitas sikap masyarakat yang 
berhubungan dengan faktor internal, faktor eksternal dan tahap-tahap partisipasi masyarakat. Pengembangan partisipasi masyarakat dalam kegiatan pengelolaan DAS Cikapundung di Kelurahan Dago dianalisis dengan menggunakan hasil analisis statistik yang menunjukkan tingkat signifikansi nyata. Lebih rinci dapat dilihat pada gambar 2. Partisipasi masyarakat di bantaran Sungai Cikapundung, Kelurahan Dago dapat dikembangkan apabila hal-hal berikut ini di perbaiki, yaitu: (1) Faktor umur dengan kecenderungan bertindak menunjukkan, bahwa golongan muda yang ada pada kisaran umur 20 - 46 tahun, perlu dijadikan kader agar kegiatan pengelolaan DAS tetap berkelanjutan;(2)Faktor tingkat pendidikan dengan tingkat pengetahuan menunjukkan, bahwa perlu adanya penyadaran akan pentingnya pendidikan formal bagi generasi penerus; (3) Faktor dukungan masyarakat dengan kecenderungan sikap dan kecenderungan bertindak menunjukkan, bahwa kontrol sosial sangat diperlukan untuk keberlanjutan kegiatan pengelolaan DAS; (4) Faktor tingkat ketersediaan fasilitas dengan kecenderungan bertindak menunjukkan, bahwa peningkatan penyediaan fasilitas sangat diperlukan sehingga kegiatan pengelolaan DAS Cikapundung dapat berkelanjutan; (5) Sumber informasi/komunikasi dengan kecenderungan sikap dan kecenderungan bertindak menunjukkan, bahwa peranan semua pihak yang terlibat sangat penting sebagai pihak utama yang menyebarkan informasi tentang kegiatan pengelolaan wilayah DAS; (6)Tingkat pengetahuan dengan tahap pemanfaatan hasil kegiatan menunjukkan, bahwa kontrol sosial sangat diperlukan untuk keberlanjutan kegiatan pengelolaan DAS; (7) Kecenderungan sikap dengan seluruh tahap partisipasi menunjukkan, bahwa proses penyadaran tentang lingkungan sangat diperlukan untuk meningkatkan kesadaran masyarakat akan pentingnya menjaga dan melestarikan lingkungan sekitar.

\section{Kesimpulan}

Kesimpulan penelitian ini yaitu: 1) partisipasi paling banyak responden terdapat pada kategori sedang, 2) faktor internal yang berhubungan nyata dengan sikap pengelolaan DAS, yaitu (a) kegiatan pengelolaan DAS kurang melibatkan masyarakat yang sebagian besar berada pada selang umur 2046 tahun, dan (b) tingkat pendidikan dan tingkat pengetahuan yang tergolong rendah, 3) faktor eksternal yang berhubungan nyata dengan intensitas sikap pengelolaan DAS, yaitu (a) dukungan masyarakat sekitar, (b) sumber informasi/komunikasi, 4) hterdapat hubungan nyata antara intensitas sikap pengelolaan DAS dengan tingkat partisipasi masyarakat

\section{Daftar Pustaka}

Ahmadi. 2009. Psikologi Sosial. Jakarta (ID): Rineka Cipta

Amzu. 2007. Sikap Masyarakat dan Konservasi: Suatu Analisis (Parkia Tumoriana (DC) Merr.) Sebagai Stimulus Tumbuhan Obat Bagi Masyarakat. Kasus di Taman Nasional Meru Betiri. [disertasi]. Bogor (ID): Sekolah Pasca Sarjana. Institut Pertanian Bogor.

Anantanyu. 2009.Partisipasi Petani dalam meningkatkan Kapasitas Kelembagaan Kelompok Petani (Kasus di Provinsi Jawa Tengah). [disertasi]. Bogor (ID): Sekolah Pasca Sarjana. Institut Pertanian Bogor.

Arnstein. 1969. A Ladder of Citizen Participation. Journal of the America Institute of Planners. [internet]. [dapat diunduh dari: http://lithgowschmidt.dk/sherry-arnstein/ladder-of-citizenparticipation en.pdf]

Bakker. 2009. Transboundary River Floods and Institutional capacity. Dalam: Journal of the American Water Resources Association. 45(3):553-566. [internet]. [dapat diunduh: http://web.ebscohost.com/ehost/pdf].

Bungin. 2009. Sosiologi Komunikasi: Teori, Paradigma, dan Diskursus Teknologi Komunikasi di Masyarakat. Jakarta (ID): Kencana Prenada Media Group

Guilford. 1956. Fundamental Statistics in Psycology and Education. New York: McGraw-Hill Companies. [internet]. [dapat diunduh dari: https://www.goodreads.com].

Halimatusadiah, dharmawan, Mardiana.2012. Efektivitas Kelembagaan Partisipatoris di Hulu Daerah Aliran Sungai Citarum. Sodality. 06(01):71-90. [internet]. [dapat diunduh dari: http://jurnalsodality.ipb.ac.id].

Handayani. 2008. Partisipasi Masyarakat Kampung Kota untuk Meningkatkan Kualitas Lingkungan Permukiman (Kasus: Permukiman Kampung Kota di Bandung). [disertasi]. Bogor (ID): Institut Pertanian Bogor

Karyana. 2007. Analisis Posisi dan Peran Lembaga Serta Pengembangan Kelembagaan di Daerah 
Aliran Sungai (DAS) Ciliwung. [disertasi]. Bogor (ID): Institut Pertanian Bogor

Kurniyanto. 2011. Strategi Pengembangan Kelembagaan

Kegiatan Rehabilitasi Hutan dan Lahan Partisipatif (RHLP) di DAS Cikundul Kabupaten Cianjur. [tesis]. Bogor (ID): Institut Pertanian Bogor

Nuddin. 2007. Analisis Sistem Kelembagaan dalam Perencanaan dan Strategi Pengelolaan Lahan Kritis DAS Bila. [disertasi]. Bogor (ID): Institut Pertanian Bogor

Rakhmat. 2003. Psikologi Komunikasi. Bandung (ID): PT. Remaja Rosdakarya

Soekanto. 1990. Sosiologi Suatu Pengantar. Jakarta (ID): PT. RajaGrafindo Persada

Tampubolon.2007. Pengaruh Kualitas Lingkungan Terhadap Biaya Eksternalitas Pengguna Air Citarum. [disertasi]. Bogor (ID): Institut Pertanian Bogor

[UU] Undang-Undang Republik Indonesia Nomor 7 Tahun 2004 Tentang Sumber Daya Air
[UU] Undang-Undang Republik Indonesia Nomor 22 Tahun 1999 Tentang Pemerintah Daerah Uphoff, Cohen, Goldsmith. 1979. Feasibility and Application of Rural Development Participation: A State-of-the-Art Paper. New York (US): Cornell University

Wahyudin. 2004. Partisipasi Masyarakat Lokal dalam Progran Pengembangan Masyarakat: Kasus Program Community Development PT. Newmont Nusa Tenggara di Desa Sekongkang Bawah, Kecamatan Sekongkang, Kabupaten Sumbawa. [tesis]. Bogor (ID): Institut Pertanian Bogor

Yuliatin. 2002. Tingkat kedinamisan Kelompok Tani dan Transmigran dalam Upaya Pengembangan Kemandirian Anggota Kelompok Tani (Kasus Petani Padi Sawah di Dua Desa Kecamatan Lambuya, Kabupaten Kendari, Provinsi Sulawesi Tenggara). [tesis]. [Internet]. [dapat diunduh dari: http://repository.ipb.ac.id]. 